\title{
Exploration of Low-Cost Solid Waste Coffee Processing to Bio-Carotenoids Production
}

\section{Mariana Dias Moreira ${ }^{1}$, Jéssica Marques Coimbra ${ }^{1}$, Marcela Magalhães Melo ${ }^{1}$, Luciana Silva Ribeiro ${ }^{1}$, Kelly Cristina dos Reis ${ }^{2}$, Rosane Freitas Schwan ${ }^{1}$ and Cristina Ferreira Silva ${ }^{1 *}$}

${ }^{1}$ Department of Biology, Federal University of Lavras, Brazil

${ }^{2}$ Department of Hydraulic and Environmental Engineering, Federal University of Ceará, Brazil

*Corresponding Author: Cristina Ferreira Silva, Associate Professor of Agricultural Microbiology, Department of Biology, Federal University of Lavras (UFLA), Brazil.
Received: July 14, 2021

Published: August 19, 2021

(C) All rights are reserved by Cristina Ferreira Silva., et al.

\begin{abstract}
To solve the high-cost production of natural microbial carotenoids, we sought to use coffee processing of low-cost solid waste, as well as high productivity. In this sense, coffee pulp extract (PE) and coffee husk extract (HE) supplemented were used as substrate to carotenoids production by two yeast strain Rhodotorula mucilaginosa CCMA 0156 and CCMA 0340, and one bacteria strain, Dermacoccus nishinomiyaensis CCMA 0685. Three different solvents were used for the extraction and recovery of intracellular carotenoids. The productivity was evaluated employing Plackett-Burman design and Central Composite Design. Maximum specific carotenoids production (361.29 $\left.\pm 36.0 \mu \mathrm{g} \mathrm{g}^{-1}\right)$ was obtained in maximum pulp extract and peptone concentration $\left(6.68 \%\right.$ e $10.04 \mathrm{~g} \mathrm{~L}^{-1}$, respectively) and middle concentration of yeast extract $\left(3 \mathrm{~g} \mathrm{~L}^{-1}\right)$ by CCMA 0156 . Both the pulp and the husk supplemented were suitable substrates to produce carotenoids with maximum production of 361 and $296 \mu \mathrm{g}^{-1}$. The supplementations shall be carried out; however, it is possible replace pure chemical for by-products. After the optimization process, carotenoid production in PE and HE increased 4.43-fold and 3.08-fold, respectively. The best extract process was using acetone: methanol (7:3, v/v). To reduce the cost of carotenoids production the use of solid waste from coffee processing is a good alternative without lose the productivity by yeasts.
\end{abstract}

Keywords: Waste Coffee; Carotenoid; Rhodotorula mucilaginosa; Dermacoccus nishinomiyaensis

\section{Abbreviations}

PE: Coffee Pulp Extract; HE: Coffee Husk Extract; DM: Dry Matter; AOAC: Association of Official Agricultural Chemists; CCMA: Culture Collection of Agricultural Microbiology; YM: Yeast Malt Extract; DMSO: Dimethyl Sulfoxide; DNS: 3,5-dinitrosalicylic Acid

\section{Introduction}

The carotenoids are a group composed of liposoluble natural pigments responsible for the yellow, orange and red found in many plants, animals and microorganisms [1-3].
Nowadays, the carotenoids are desirable compounds in several industries such as chemical, pharmaceutical, food and cosmetics [4]. These pigments have attracted the attention of industry and researchers because they can act as vitamin A precursors and feature antioxidant properties. Carotenoids are natural antioxidants that can relieve chronic diseases, retard aging, and reduce various disease stages $[4,5]$.

Industrially, the pigments used are extracts from plants or algae. However, there are disadvantage as low productivity, high 
costs production and climate dependent production [6,7]. These can be solved by fermentation since microorganism species naturally synthesized pigments $[8,9]$. The challenge is finding production system with low cost and high yield that also, include adequate pigment extraction.

One alternative is used inexpensive substrates such as agroindustrial waste in optimized process [7]. Different agro-industrial waste already used to biotechnological proposes as biocarotenoids production like waste flour, fermented radish brine, whole stillage, grape juice, wheat straw, parboiled rice water, crude glycerol, molasses, and cheese [10]. Others like husk and pulp coffee should be considered.

The principal microorganisms cited as pigments producers are yeasts (Rhodotorula, Xanthophyllomyces dendrorhous, Cryptococcus), bacteria (Rhodobacter, Streptomyces, Mycobacterium), alga (Dunaliella) and filamentous fungi (Penicillium oxalicum, Blakeslea trispora, Aashbya gossypii) [11]. The pigments for microorganisms chemoorganotrophic represent protection against UV rays avoiding photo-oxidative damage [7]. Therefore, pigments are synthesized and stored inside of the cells and needs to recovery for industrial application representing a big challenge $[12,13]$.

The extraction can be carried out using organic solvents such as acetone, petroleum ether, hexane, chloroform, ethanol, and methanol $[14,15]$ showing synergistic interactions which results in higher yields of carotenoids [16]. In this way, in view of the challenge of environmentally friendly process join to natural products of the consumers, this work proposes the use of pulp and coffee peel for bioproduction of carotenoids.

\section{Materials and Methods}

By-products

Coffee husk and pulp from dry and semi-dry process, respectively, of the coffee beans (Coffea arabica L., variety red Catuaí 99) was supplied by a coffee-producing unit located in the southern area of the state of Minas Gerais (21 $14^{\circ} 45^{\prime \prime} \mathrm{S}, 44^{\circ} 59^{\prime} 59^{\prime \prime} \mathrm{W}$ ) (Brazil). The by-products were immediately frozen at $-20^{\circ} \mathrm{C}$. Before the use, the husk and pulp coffee were dried at $65^{\circ} \mathrm{C}$, separately, until them reached a constant weight [17], ground in Willey mill $(1.0 \mathrm{~mm})$ and stored in plastic flasks.
Pretreatment

To correct the $\mathrm{pH}$ of each substrate, a pretreatment was carried out. For this, $50 \mathrm{~g}$, the pulp, or husk, was resuspended in $1 \mathrm{~L}$ of distilled water containing $\mathrm{KOH} 0.06 \%(\mathrm{w} / \mathrm{v})$ and sterilization was carried out at $121^{\circ} \mathrm{C} / 30 \mathrm{~min}$ [18]. The extracts were filtered with Whatman $\mathrm{N}^{\circ} 1$ and used for fermentation medium.

\section{Physicochemical analysis of solid waste}

Crude protein and dry matter (DM) content were done according to AOAC [17]. Total soluble carbohydrates were determined by phenol-sulfuric method [19], with modifications, and $\mathrm{pH}$ was determined by using a digital potentiometer (Digimed analytical, Model DM22).

Screening of microorganisms to carotenoids production in waste coffee

Two orange color yeasts, Rhodotorula mucilaginosa CCMA 0156 and CCMA 0340, and one yellow color bacteria, Dermacoccus nishinomiyaensis CCMA 0685 were selected for production of carotenoids. The strains belonging to the Culture Collection of Agricultural Microbiology (CCMA) of Biology Department, Federal University of Lavras, Brazil. The strain has been highest carotenoids production was submitted to experimental design.

To test the isolates would be able to grow and producing carotenoids from husk extract or coffee pulp extract as substrate $(50 \mathrm{~g}$ $\mathrm{L}^{-1}$ each one), we use firstly, the fermentation without addition of any nutrients. To compare synthetic medium YM (Yeast Malt Extract) $\left(\mathrm{g} \mathrm{L}^{-1}\right)$ : 3.0 yeast extract, 3.0 malt extract, 5.0 peptone and 10.0 glucose) was also used.

For this, initially, each isolate was reactivated in $1 \mathrm{~mL}$ of YM medium and growth for $24 \mathrm{~h}$. Whole volume was added in tube filled $9 \mathrm{~mL}$ YM medium for $24 \mathrm{~h}$. The same was carried out in Erlenmeyer flasks of $250 \mathrm{~mL}$ with $90 \mathrm{~mL}$ of the YM medium and incubated for $48 \mathrm{~h}$. The cells were centrifuged at $9000 \mathrm{rpm}, 4^{\circ} \mathrm{C} / 10 \mathrm{~min}$ and washed 2 times with distilled water. The cultivations were carried out in $500 \mathrm{~mL}$ Erlenmeyer flasks containing $300 \mathrm{~mL}$ of medium (YM, PE, or HE) inoculated with $10^{7} \mathrm{CFU} \mathrm{mL}^{-1}$ and incubated at $28^{\circ} \mathrm{C}, 160 \mathrm{rpm} / 4$ days in the dark. The experiments were conducted in triplicate, totalized 27 assays. After of $4^{\text {th }}$ day, the carotenoid was extracted, recovered, and quantified. 


\section{Extraction and carotenoids recovery}

From each assay the carotenoid produced were recovered by three different extraction methods [20]. The solvent mixtures used were as follows: Method 1 - acetone: methanol (7: 3,v/v); Method 2 - acetone: petroleum ether $(1: 1, \mathrm{v} / \mathrm{v})$; and Method 3 - ethyl acetate: petroleum ether $(1: 1, \mathrm{v} / \mathrm{v})$. The cell disruption step was similarly for all three methods. The microbial biomass recovered from the fermentation medium was centrifuged $\left(9,000 \times \mathrm{g}, 4^{\circ} \mathrm{C} / 10 \mathrm{~min}\right)$ and dried in oven at $65^{\circ} \mathrm{C} / 24 \mathrm{~h}$. After the drying step, the biomass was macerated in liquid $\mathrm{N}_{2}$ and added $2 \mathrm{~mL}$ of dimethyl sulfoxide (DMSO), heated in a water bath at $55^{\circ} \mathrm{C} / 30 \mathrm{~min}$. After this time, $2 \mathrm{~mL}$ of each mixture of solvents (method 1, 2 or 3) were added and centrifuged $\left(5,000 \times \mathrm{g}, 4^{\circ} \mathrm{C}, 10 \mathrm{~min}\right)$. The supernatant was separated, and successive extractions were carried out until biomass remains colorless. The solvent was evaporated in nitrogen gas atmosphere and pigment was solubilized in $5 \mathrm{~mL}$ methanol (99\%) from method 1, and $5 \mathrm{~mL}$ of petroleum ether from method 2 or 3.

\section{Quantification of total carotenoids}

The concentration of total carotenoids was estimated from each sample, after the extraction and recovery, by the maximum absorbance at $450 \mathrm{~nm}$, using the equation described by Davies (1976). The coefficient of absorbance used was referent to beta $(\beta)$-carotene: $\mathrm{E}_{1 \mathrm{~cm}}^{1 \%}=2592$, for petroleum ether solution and $\mathrm{E}^{1 \%}{ }_{1 \mathrm{~cm}}$ $=2550$, for methanol solution [21]. Concentration of carotenoids was expressed in total carotenoids $\left(\mu \mathrm{g} \mathrm{L}^{-1}\right)$ and specific production of carotenoids $\left(\mu \mathrm{g} \mathrm{g}^{-1}\right)$. This represents the total concentration of carotenoids $(\mu \mathrm{g})$ in relation to the biomass of dried yeast or bacteria obtained in $1 \mathrm{~L}$ of a fermented medium [22].

Determination of biomass, reducing sugar, $\mathrm{pH}$, and cell count

After carotenoids extraction, the cells were washed with distilled water and centrifuged at $5,000 \times \mathrm{g}$ at $4^{\circ} \mathrm{C} / 10 \mathrm{~min}$. The biomass was quantified drying at $65^{\circ} \mathrm{C}$ until a constant weight. Reducing sugar was measured by DNS (3,5-dinitrosalicylic acid) methodology as described by Miller [23] and the staining intensity was measured by spectrophotometer (Biospectro, Model SP-220) at $540 \mathrm{~nm}$. The $\mathrm{pH}$ of culture media was determined using a digital pH meter (Digimed analytical, Model DM22). Cell growth was evaluated by counting in Neubauer Chamber (yeast) and counting in plate (bacteria).

\section{Optimization of carotenoids production}

The different medium composition and the fermentation conditions were assessed by a Plackett-Burman Design (Screening Design) with twelve assays and three central points [24]. Experimental variables and their corresponding levels are summarized in table 1.

\begin{tabular}{|c|c|c|c|c|}
\hline \multirow{2}{*}{ Variables } & \multirow{2}{*}{ Codes } & \multicolumn{3}{|c|}{ Levels } \\
\hline & & -1 & 0 & +1 \\
\hline $\mathrm{pH}$ & $\mathrm{X}_{1}$ & 4 & 6 & 8 \\
\hline Glucose $\left(\mathrm{g} \mathrm{L}^{-1}\right)$ & $\mathrm{X}_{2}$ & 0 & 2 & 4 \\
\hline Yeast extract $\left(\mathrm{g} \mathrm{L}^{-1}\right)$ & $\mathrm{X}_{3}$ & 0 & 1 & 3 \\
\hline Malt extract $\left(\mathrm{g} \mathrm{L}^{-1}\right)$ & $\mathrm{X}_{4}$ & 0 & 1 & 3 \\
\hline Ammonium sulfate $\left(\mathrm{g} \mathrm{L}^{-1}\right)$ & $\mathrm{X}_{5}$ & 0 & 1 & 2 \\
\hline Tween $80(\%)$ & $\mathrm{X}_{6}$ & 0 & 0,5 & 1 \\
\hline Peptone $\left(\mathrm{g} \mathrm{L}^{-1}\right)$ & $\mathrm{X}_{7}$ & 0 & 2 & 5 \\
\hline $\begin{array}{l}\text { Pulp extract or husk extract } \\
(\%)\end{array}$ & $\mathrm{X}_{8}$ & 1 & 3 & 5 \\
\hline
\end{tabular}

Table 1: Variables and levels used in the Plackett-Burman planning type for the screening means design with coffee pulp extract and husk extract for carotenoids production by Rhodotorula mucilaginosa CCMA 0156.

The isolate showed best carotenoid production (described previously) was used in optimization design (CCDR), $2^{3}$ design, being three replications of the center points, and six axial points (Table 2 and 3). Total carotenoid $\left(\mu \mathrm{g} \mathrm{L}^{-1}\right)$, specific carotenoid production $(\mu \mathrm{g}$ $\left.\mathrm{g}^{-1}\right)$ and biomass $\left(\mathrm{g} \mathrm{L}^{-1}\right)$ were the dependent variables. After that, RSM was employed to obtain the theoretical optimum condition.

The preparation of the Rhodotorula mucilaginosa CCMA 0156 inoculum was done, as described in the previous section, with inoculum size of the $10.0 \%(\mathrm{w} / \mathrm{v})$ at $10^{7} \mathrm{cel} \mathrm{mL}^{-1}$. The assays were carried out in $250 \mathrm{~mL}$ Erlenmeyer flasks containing $150 \mathrm{~mL}$ of medium and incubated at $28^{\circ} \mathrm{C}, 160 \mathrm{rpm} / 5$ days in the dark.

\section{Validation of the experimental design}

The validations experiment carotenoids production was performed both for coffee pulp extract (PE) and coffee husk extract (HE). The validation was carried out under the optimized conditions indicated by the STATISTICA 8.0 software. The model was 


\begin{tabular}{|l|c|c|c|}
\hline Assays & Pulp extract $\mathbf{X}_{1}$ & Peptone $\mathbf{X}_{2}$ & Yeast extract $\mathbf{X}_{3}$ \\
\hline 1 & $-1(3 \%)$ & $-1\left(2 \mathrm{~g} \mathrm{~L}^{-1}\right)$ & $-1\left(1 \mathrm{~g} \mathrm{~L}^{-1}\right)$ \\
\hline 2 & $1(7 \%)$ & $-1\left(2 \mathrm{~g} \mathrm{~L}^{-1}\right)$ & $-1\left(1 \mathrm{~g} \mathrm{~L}^{-1}\right)$ \\
\hline 3 & $-1(3 \%)$ & $1\left(8 \mathrm{~g} \mathrm{~L}^{-1}\right)$ & $-1\left(1 \mathrm{~g} \mathrm{~L}^{-1}\right)$ \\
\hline 4 & $1(7 \%)$ & $1\left(8 \mathrm{~g} \mathrm{~L}^{-1}\right)$ & $-1\left(1 \mathrm{~g} \mathrm{~L}^{-1}\right)$ \\
\hline 5 & $-1(3 \%)$ & $-1\left(2 \mathrm{~g} \mathrm{~L}^{-1}\right)$ & $1\left(5 \mathrm{~g} \mathrm{~L}^{-1}\right)$ \\
\hline 6 & $1(7 \%)$ & $-1\left(2 \mathrm{~g} \mathrm{~L}^{-1}\right)$ & $1\left(5 \mathrm{~g} \mathrm{~L}^{-1}\right)$ \\
\hline 7 & $-1(3 \%)$ & $1\left(8 \mathrm{~g} \mathrm{~L}^{-1}\right)$ & $1\left(5 \mathrm{~g} \mathrm{~L}^{-1}\right)$ \\
\hline 8 & $1(7 \%)$ & $1\left(8 \mathrm{~g} \mathrm{~L}^{-1}\right)$ & $1\left(5 \mathrm{~g} \mathrm{~L}^{-1}\right)$ \\
\hline 9 & $-1,68(1.64 \%)$ & $0\left(5 \mathrm{~g} \mathrm{~L}^{-1}\right)$ & $0\left(3 \mathrm{~g} \mathrm{~L}^{-1}\right)$ \\
\hline 10 & $1,68(6.36 \%)$ & $0\left(5 \mathrm{~g} \mathrm{~L}^{-1}\right)$ & $0\left(3 \mathrm{~g} \mathrm{~L}^{-1}\right)$ \\
\hline 11 & $0(5 \%)$ & $-1,68\left(0.04 \mathrm{~g} \mathrm{~L}^{-1}\right)$ & $0\left(3 \mathrm{~g} \mathrm{~L}^{-1}\right)$ \\
\hline 12 & $0(5 \%)$ & $1,68\left(10.04 \mathrm{~g} \mathrm{~L}^{-1}\right)$ & $0\left(3 \mathrm{~g} \mathrm{~L}^{-1}\right)$ \\
\hline 13 & $0(5 \%)$ & $0\left(5 \mathrm{~g} \mathrm{~L}^{-1}\right)$ & $-1,68\left(0.36 \mathrm{~g} \mathrm{~L}^{-1}\right)$ \\
\hline 14 & $0(5 \%)$ & $0\left(5 \mathrm{~g} \mathrm{~L}^{-1}\right)$ & $1,68\left(6.36 \mathrm{~g} \mathrm{~L}^{-1}\right)$ \\
\hline 15 & $0(5 \%)$ & $0\left(5 \mathrm{~g} \mathrm{~L}^{-1}\right)$ & $0\left(3 \mathrm{~g} \mathrm{~L}^{-1}\right)$ \\
\hline 16 & $0(5 \%)$ & $0\left(5 \mathrm{~g} \mathrm{~L}^{-1}\right)$ & $0\left(3 \mathrm{~g} \mathrm{~L}^{-1}\right)$ \\
\hline 17 & $0(5 \%)$ & $0\left(5 \mathrm{~g} \mathrm{~L}^{-1}\right)$ & $0\left(3 \mathrm{~g} \mathrm{~L}^{-1}\right)$ \\
\hline
\end{tabular}

\begin{tabular}{|l|c|c|c|}
\hline Assays & Glucose X & Peptone X & Husk extract $\mathbf{X}_{3}$ \\
\hline 1 & $-1\left(1 \mathrm{~g} \mathrm{~L}^{-1}\right)$ & $-1\left(1 \mathrm{~g} \mathrm{~L}^{-1}\right)$ & $-1(3 \%)$ \\
\hline 2 & $1\left(5 \mathrm{~g} \mathrm{~L}^{-1}\right)$ & $-1\left(1 \mathrm{~g} \mathrm{~L}^{-1}\right)$ & $-1(3 \%)$ \\
\hline 3 & $-1\left(1 \mathrm{~g} \mathrm{~L}^{-1}\right)$ & $1\left(3 \mathrm{~g} \mathrm{~L}^{-1}\right)$ & $-1(3 \%)$ \\
\hline 4 & $1\left(5 \mathrm{~g} \mathrm{~L}^{-1}\right)$ & $1\left(3 \mathrm{~g} \mathrm{~L}^{-1}\right)$ & $-1(3 \%)$ \\
\hline 5 & $-1\left(1 \mathrm{~g} \mathrm{~L}^{-1}\right)$ & $-1\left(1 \mathrm{~g} \mathrm{~L}^{-1}\right)$ & $1(7 \%)$ \\
\hline 6 & $1\left(5 \mathrm{~g} \mathrm{~L}^{-1}\right)$ & $-1\left(1 \mathrm{~g} \mathrm{~L}^{-1}\right)$ & $1(7 \%)$ \\
\hline 7 & $-1\left(1 \mathrm{~g} \mathrm{~L}^{-1}\right)$ & $1\left(3 \mathrm{~g} \mathrm{~L}^{-1}\right)$ & $1(7 \%)$ \\
\hline 8 & $1\left(5 \mathrm{~g} \mathrm{~L}^{-1}\right)$ & $1\left(3 \mathrm{~g} \mathrm{~L}^{-1}\right)$ & $1(7 \%)$ \\
\hline 9 & $-1,68\left(0.36 \mathrm{~g} \mathrm{~L}^{-1}\right)$ & $0\left(2 \mathrm{~g} \mathrm{~L}^{-1}\right)$ & $0(5 \%)$ \\
\hline 10 & $1,68(6.36 \%)$ & $0\left(2 \mathrm{~g} \mathrm{~L}^{-1}\right)$ & $0(5 \%)$ \\
\hline 11 & $0\left(3 \mathrm{~g} \mathrm{~L}^{-1}\right)$ & $-1,68\left(0.32 \mathrm{~g} \mathrm{~L}^{-1}\right)$ & $0(5 \%)$ \\
\hline 12 & $0\left(3 \mathrm{~g} \mathrm{~L}^{-1}\right)$ & $1,68\left(3.68 \mathrm{~g} \mathrm{~L}^{-1}\right)$ & $0(5 \%)$ \\
\hline 13 & $0\left(3 \mathrm{~g} \mathrm{~L}^{-1}\right)$ & $0\left(2 \mathrm{~g} \mathrm{~L}^{-1}\right)$ & $-1,68(1.64 \%)$ \\
\hline 14 & $0\left(3 \mathrm{~g} \mathrm{~L}^{-1}\right)$ & $0\left(2 \mathrm{~g} \mathrm{~L}^{-1}\right)$ & $1,68(8.36 \%)$ \\
\hline 15 & $0\left(3 \mathrm{~g} \mathrm{~L}^{-1}\right)$ & $0\left(2 \mathrm{~g} \mathrm{~L}^{-1}\right)$ & $0(5 \%)$ \\
\hline 16 & $0\left(3 \mathrm{~g} \mathrm{~L}^{-1}\right)$ & $0\left(2 \mathrm{~g} \mathrm{~L}^{-1}\right)$ & $0(5 \%)$ \\
\hline 17 & $0\left(3 \mathrm{~g} \mathrm{~L}^{-1}\right)$ & $0\left(2 \mathrm{~g} \mathrm{~L}^{-1}\right)$ & $0(5 \%)$ \\
\hline
\end{tabular}

Table 2: CCDR matrix (real and coded values) of three variables (pulp extract, peptone, and yeast extract) used in the production of carotenoids by Rhodotorula mucilaginosa CCMA 0156 in coffee pulp extract (PE), $28^{\circ} \mathrm{C}, 160 \mathrm{rpm}$ in the dark for 5 days.

tested in triplicate assays using $150 \mathrm{~mL}$ of culture medium, at 160 $\mathrm{rpm}, \mathrm{pH} 5.28,28^{\circ} \mathrm{C} / 120 \mathrm{~h}$ in the dark. The medium composition using pulp extract was $\mathrm{X}_{1}$ - pulp extract $(6.68 \%), \mathrm{X}_{2}$ - peptone $(10.04$ $\left.\mathrm{g} \mathrm{L}^{-1}\right), \mathrm{X}_{3}$ - yeast extract $\left(3 \mathrm{~g} \mathrm{~L}^{-1}\right)$ and glucose $\left(2 \mathrm{~g} \mathrm{~L}^{-1}\right)$ and tween 80 $(0.5 \%)$ as fixed factors. In husk extract $X_{1}$-glucose $\left(6.36 \mathrm{~g} \mathrm{~L}^{-1}\right), \mathrm{X}_{2}$ peptone (3.68 $\left.\mathrm{g} \mathrm{L}^{-1}\right), \mathrm{X}_{3}$-husk extract (8.36\%) and tween $80(0.5 \%)$ as fixed factor.

\section{Statistical analysis}

The results obtained from all experiments were subjected to analysis of variance (ANOVA), applying entirely randomized design, with factorial arrangement $3 \times 3$ ( 3 extraction methods and 3 culture media), using Sisvar ${ }^{\circledR} 4.5$ (Lavras, Brazil) software. The Ftest was used to determine significant effects of the treatments and Scott-Knott test was used to compare the average of replicates at a $5 \%$ level of significance. The results obtained from experimental design were analyzed using the statistical software Statistica 8.0

Table 3: CCDR matrix (coded and real values) of three variables (glucose, peptone, and husk extract) used in the production of carotenoids by Rhodotorula mucilaginosa CCMA 0156 in coffee husk extract (HE), $28^{\circ} \mathrm{C}, 160 \mathrm{rpm}$ in the dark for 5 days.

(Stat soft. Inc. ${ }^{\circledR}$, Tulsa). The statistical significance of the model was determined using Fisher's test. The fit of the regression model was checked by the adjusted coefficient of determination $\mathrm{R}^{2}$. Response surface plots were generated by the same software. Finally, the location of the optimum condition was calculated by differentiation of the quadratic model.

\section{Results and Discussion}

Characterization of by-products

The pulp and husks coffee were naturally acidic, ranged from 4.5 to 4.7, pulp and husk coffee, respectively. After the pretreatment with $\mathrm{KOH}$, the $\mathrm{pH}$ of the extracts was slightly changed to 5.0 (pulp extract) and 5.7 (husk extract) (Table 4). The chemical composition of these by-products was similar both in natura and pretreated (Table 4), except to dry matter content that in pretreated there was lost after pretreatment (80 and 69\%), as expected. 


\begin{tabular}{|l|c|c|c|c|}
\hline \multirow{2}{*}{ Parameters } & \multicolumn{2}{|c|}{ In natura } & \multicolumn{2}{c|}{ Pretreated } \\
\cline { 2 - 5 } & $\begin{array}{c}\text { Coffee } \\
\text { pulp }\end{array}$ & $\begin{array}{c}\text { Coffee } \\
\text { husk }\end{array}$ & $\begin{array}{c}\text { Coffee } \\
\text { pulp }\end{array}$ & $\begin{array}{c}\text { Coffee } \\
\text { husk }\end{array}$ \\
\hline $\mathrm{pH}$ & 4.5 & 4.7 & 5.0 & 5.7 \\
\hline Dry matter $\left(\mathrm{g} \mathrm{Kg}^{-1}\right)$ & 1181.64 & 982.39 & 242.11 & 305.07 \\
\hline $\begin{array}{l}\text { Crude protein }\left(\mathrm{g} \mathrm{Kg}^{-1}\right. \\
\text { MS) }\end{array}$ & 173.7 & 137.23 & 171.07 & 133.79 \\
\hline $\begin{array}{l}\text { Total soluble } \\
\text { carbohydrates }\left(\mathrm{g} \mathrm{Kg}^{-1}\right. \\
\text { MS) }\end{array}$ & 156.8 & 136.15 & 120.09 & 100.7 \\
\hline
\end{tabular}

Table 4: Physicochemical composition of pulp and coffee husk in natura and after pretreatment.

The great commercial demand for natural carotenoids has drawn attention to the development of appropriate and inexpensive biotechnology techniques, including the use of agro-industrial waste as sources of carbon and/or nitrogen [25,26]. The coffee pulp and husk are the first by-products obtained during processing of the coffee fruit, representing $29 \%$ and $12 \%$ of the dry weight of the whole berry, respectively [27]. Many alternatives to use these by-products have been proposal like production of biofuel, mushroom, and fertilizer, besides extraction of enzymes, dietary fiber and bioactive compound [28], but is the first time these by-products were used to bio-carotenoids production.

These by-products have similar chemical composition. Coffee pulp and husk are rich in carbohydrates (32-35\%), proteins (7-15\%) and mineral (10.7\%), indicating that these residues are very promising for use in many biotechnological processes [29,30]. However, the application of coffee by-products in bioprocess with microorganisms can be limited due to their content of toxic substances, such as phenolic compounds and caffeine. Therefore, pretreatment of pulp and husk coffee with $\mathrm{KOH}$ is necessary for detoxifying these by-products and allow microbial growth [28].

In our study, the use of coffee by-products, pulp, and husk, for obtaining extracts of a culture medium for production of carotenoids by yeast and bacteria as an excellent alternative. As with other agro-industrial waste they are cheap and easily available produced and their use contributes to a reduction in production cost $[13,31]$. The nutrients supplemented as glucose, peptone and yeast extract could be replaced for other alternatives cheaper like molasses and soy meal extract.

Specific carotenoids production from the screening

The carotenoids production from microbial and condition media screening were recovery with three different solvents combinations (Table 5). All tested combinations of solvents showed to be suitable and statistically significant $(p<0.05)$ in the extraction of carotenoids. However, the combined solvents were different in the efficiency on production (Table 5).

From $R$. mucilaginosa CCMA 0340 the production was higher in Husk extract, $74.3 \mu \mathrm{g} \mathrm{g}^{-1}$ to $119.6 \mu \mathrm{g} \mathrm{g}^{-1}$, than in pulp extract, $57.2 \mu \mathrm{g}$ $\mathrm{g}^{-1}$ to $80.9 \mu \mathrm{g} \mathrm{g}^{-1}$. The best efficiency was in husk using by acetone/ petroleum ether extraction representing double productivity.

R. mucilaginosa CCMA 0156 stood out for the highest biomass production in pulp extract but higher specific production in husk extract (79.4 to $96.2 \mu \mathrm{g} \mathrm{g}^{-1}$ ). However, the maximum production of specific carotenoids was not accompanied by maximum production biomass $\left(2.64 \mathrm{~g} \mathrm{~L}^{-1}\right)$.

Considering the conditions of screening and fermentation parameters (see item 3.3), is possible to discard D. nishinomiyaensis CCMA 0685 for carotenoid production since showed 17 times lower production.

\section{Fermentation parameters in the screening}

In general way, total carotenoid production was accompanied by the increase in biomass production and simultaneous decrease of reducing sugars. However, the higher biomass production did not have direct correlation with the higher carotenoid production and was dependent of strain e media composition as well the total carotenoid production.

This is clear in R. mucilaginosa CCMA 0156 at $96 \mathrm{~h}$ fermentation producing maximum of carotenoids $\left(154.29 \mu \mathrm{g} \mathrm{L}^{-1}\right)$ and largest biomass production (5.64 $\mathrm{g} \mathrm{L}^{-1}$ ) in pulp extract (Figure 1B). Opposite, $R$. mucilaginosa CCMA 0340 showed 84.83\% (23.4 $\left.\mu \mathrm{g} \mathrm{L}^{-1}\right)$ carotenoid production less than $R$. mucilaginosa CCMA 0156, in pulp extract (Figure 1E).

The strains $R$. mucilaginosa CCMA 0156 and $R$. mucilaginosa CCMA 0340 consumed faster the reducing sugar in synthetic me- 


\begin{tabular}{|c|c|c|c|c|c|c|c|c|c|}
\hline \multicolumn{10}{|l|}{ Total Carotenoid $\left(\mu \mathrm{g} \mathrm{L}^{-1}\right)$} \\
\hline \multirow[b]{2}{*}{ Solvent combination* } & \multicolumn{3}{|c|}{ R. mucilaginosa CСMA 0156} & \multicolumn{3}{|c|}{ R. mucilaginosa CCMA 0340} & \multicolumn{3}{|c|}{ D. nishinomiyaensis CCMA 0685} \\
\hline & YM & PE & HE & YM & PE & HE & YM & PE & HE \\
\hline 1 & $251.3 \mathrm{aA}$ & $331.2 \mathrm{aA}$ & $255.0 \mathrm{aA}$ & $306.5 \mathrm{aA}$ & $160.5 \mathrm{bA}$ & $137.6 \mathrm{bA}$ & $16.1 \mathrm{aA}$ & $41.6 \mathrm{bA}$ & $9.3 \mathrm{aA}$ \\
\hline 2 & $184.7 \mathrm{aA}$ & $269.0 \mathrm{aA}$ & $215.0 \mathrm{aA}$ & 421.9aA & $106.2 \mathrm{bB}$ & 218.2abB & $16.2 \mathrm{aA}$ & $19.0 \mathrm{aB}$ & $11.2 \mathrm{aA}$ \\
\hline 3 & $195.2 \mathrm{aA}$ & $259.2 \mathrm{aA}$ & $250.4 \mathrm{aA}$ & $128.8 \mathrm{aB}$ & $186.8 \mathrm{aA}$ & $105.9 \mathrm{aA}$ & $30.0 \mathrm{aB}$ & $50.8 \mathrm{aA}$ & $3.4 \mathrm{bB}$ \\
\hline \multicolumn{10}{|c|}{ Specific Carotenoid $\left(\mu \mathrm{g} \mathrm{g}^{-1}\right)$} \\
\hline & \multicolumn{3}{|c|}{ R. mucilaginosa CCMA 0156} & \multicolumn{3}{|c|}{ R. mucilaginosa CCMA 0340} & \multicolumn{3}{|c|}{$\begin{array}{c}\text { D. nishinomiyaensis CCMA } \\
0685\end{array}$} \\
\hline Solvent combination* & YM & PE & HE & YM & PE & HE & YM & PE & HE \\
\hline 1 & $57.0 \mathrm{bA}$ & $81.4 \mathrm{aA}$ & $96.2 \mathrm{aA}$ & $90.8 \mathrm{aA}$ & $62.4 \mathrm{aA}$ & $74.3 \mathrm{aA}$ & $7.0 \mathrm{aA}$ & $17.6 \mathrm{bAB}$ & $8.0 \mathrm{aA}$ \\
\hline 2 & $74.3 \mathrm{aA}$ & $69.2 \mathrm{aA}$ & $79.4 \mathrm{aA}$ & $130.3 \mathrm{aA}$ & $57.2 \mathrm{bA}$ & $119.6 \mathrm{aB}$ & $6.5 \mathrm{aA}$ & $13.2 \mathrm{aA}$ & $7.4 \mathrm{aA}$ \\
\hline 3 & $62.7 \mathrm{aA}$ & $70.4 \mathrm{aA}$ & $86.1 \mathrm{aA}$ & $42.61 \mathrm{aB}$ & $80.9 \mathrm{aA}$ & 81.7aAB & $13.1 \mathrm{aA}$ & $26.9 \mathrm{bB}$ & $3.5 \mathrm{aB}$ \\
\hline \multicolumn{10}{|l|}{ Biomass ( $\left.\mathrm{g} \mathrm{L}^{-1}\right)$} \\
\hline & \multicolumn{3}{|c|}{ R. mucilaginosa CCMA 0156} & \multicolumn{3}{|c|}{ R. mucilaginosa CCMA 0340} & \multicolumn{3}{|c|}{$\begin{array}{c}\text { D. nishinomiyaensis CCMA } \\
0685\end{array}$} \\
\hline Solvent combination* & YM & PE & HE & YM & PE & HE & YM & PE & HE \\
\hline 1 & $4.4 \mathrm{aA}$ & $4.0 \mathrm{aA}$ & $2.6 \mathrm{bA}$ & $3.3 \mathrm{aA}$ & $2.5 \mathrm{aA}$ & $1.8 \mathrm{aA}$ & $2.3 \mathrm{aA}$ & $2.3 \mathrm{aA}$ & $1.1 \mathrm{bA}$ \\
\hline 2 & $2.4 \mathrm{aB}$ & $3.8 \mathrm{bA}$ & $2.7 \mathrm{abA}$ & $3.2 \mathrm{aA}$ & $1.8 \mathrm{bA}$ & $1.8 \mathrm{bA}$ & $2.4 \mathrm{aA}$ & $1.4 \mathrm{bA}$ & $1.5 \mathrm{bA}$ \\
\hline 3 & $3.1 \mathrm{aB}$ & $3.6 \mathrm{aA}$ & $3.0 \mathrm{aA}$ & $3.0 \mathrm{aA}$ & $2.3 \mathrm{aA}$ & $1.3 \mathrm{bA}$ & $2.3 \mathrm{aA}$ & $1.8 \mathrm{aA}$ & $1.0 \mathrm{bA}$ \\
\hline
\end{tabular}

Table 5: Concentration of total carotenoids, specific and biomass produced by strains Rhodotorula mucilaginosa CCMA 0156, Rhodotorula mucilaginosa CCMA 0340 and Dermacoccus nishinomiyaensis CCMA 0685 in different culture medium (YW, PE and HE) and three different extraction methods.

Means followed by the same capital letters, in columns, and means with the same lowercase letters, in rows, do not differ by the Scott Knott test $(\mathrm{p}<0.05)$.

YM - Synthetic medium; PE - coffee pulp extract; HE - coffee husk extract.

*Method 1- acetone: methanol (7: 3,v/v); method 2 - acetone: petroleum ether (1:1,v/v); and method 3 - ethyl acetate: petroleum ether $(1: 1, v / v)$.

dium, where consumption was $84 \%$ and $87 \%$, respectively, then in pulp extract and husk extract where the sugar consumption was around 70\%. In the same way, D. nishinomiyaensis CCMA 0685 had higher consumption in synthetic medium (44\%) than in pulp extract $(22 \%)$ and husk extract (18\%).

The $\mathrm{pH}$ was monitored throughout the fermentation (Figure 1). The $\mathrm{pH}$ evolution during production of carotenoids was similar to three strains. The first $48 \mathrm{~h}$ there was a decrease from $\mathrm{pH}$ initial and during intense cell carotenogenesis phase $\mathrm{pH}$ increased (Figure 1).

Carotenoid yeast and bacteria accumulate in lipid particles in the cell and therefore can be extracted using various organic solvents (e.g. acetone, petroleum ether, hexane, ethyl ether, dichloromethane, methanol). The efficiency of the method varies depending on the characteristics of the microbial cells like the presence of a cell wall and the influence of the cell surface [32]. However, there is still no standard technique to ensure maximum efficiency of extraction for any microorganism [32]. Recovery of carotenoids of cells R. mucilaginosa CCMA 0156, R. mucilaginosa CCMA 0340 and
Dermacoccus nishinomiyaensis CCMA 0685 was tested using three different methods of extraction with chemical solvents. All solvent combinations were effective in the extraction of carotenoids, but with differences in performance of recovery. Studies report that mixtures of solvents are more efficient than a pure solvent on recovery of intracellular synergistic effect due to carotenoids [33].

The carotenoids production in three different media culture and recovery extracted by the three solvent organic combination were statistically significant. The differences are associated with each studied strain due their cell characteristics, the way of maceration of the cells and the degree of rupture with liquid nitrogen, among others [16]. In our study, the maximum production of carotenoids by Rhodotorula mucilaginosa CCMA 0156 was observed during the stationary phase (data not shown) at $96 \mathrm{~h}$ of fermentation. In addition, the maximum yield was accompanied by maximal production of biomass, as reported in the literature. The accumulation of carotenoids in most yeast cells and bacteria starts in the late log phase and continues in the stationary phase [34]. Valduga., et al. [35], studying yeast Sporidiobolus salmonicolor (CBS 2636), 

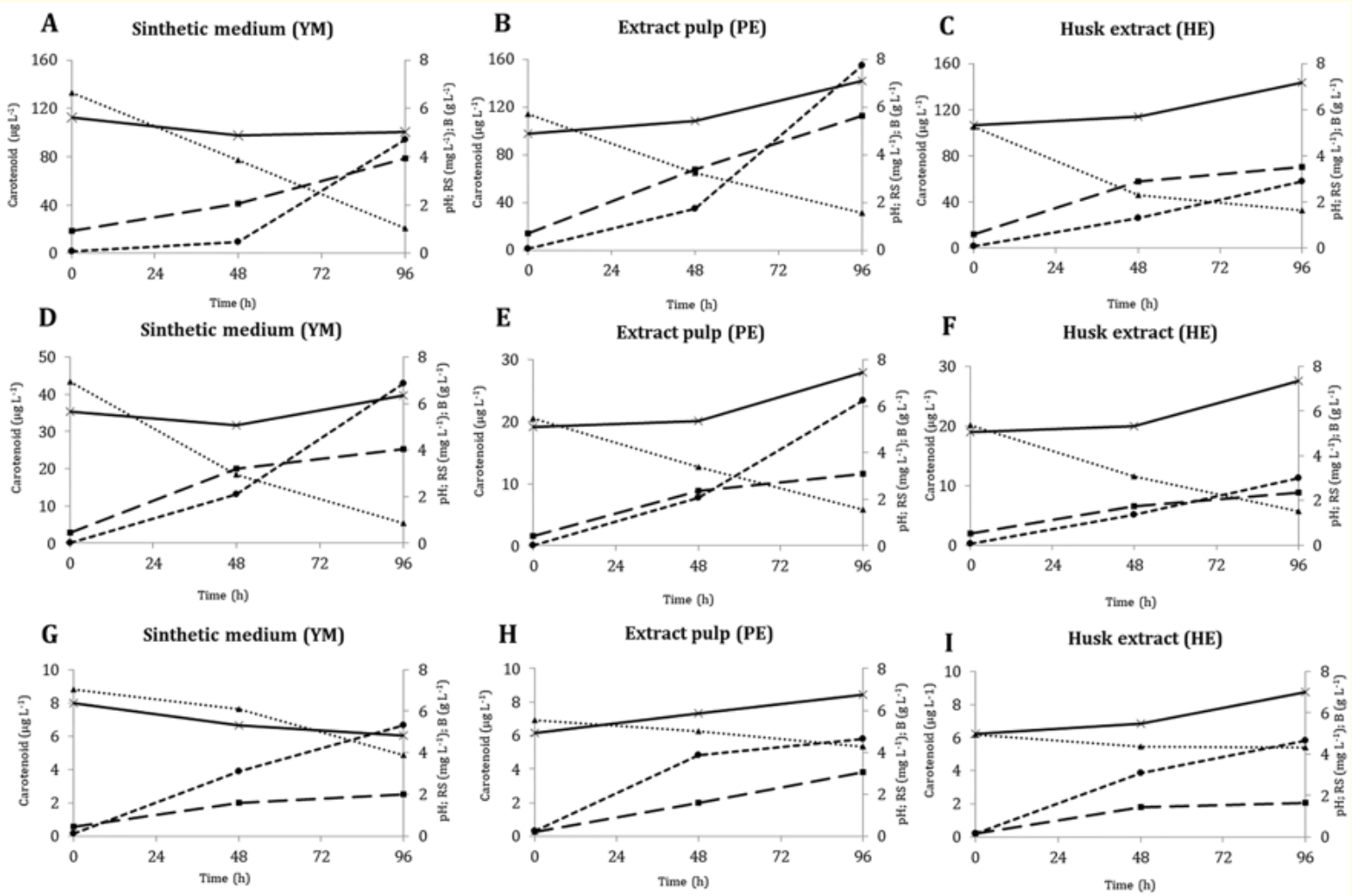

Figure 1: Kinetics of the fermentation, $\mathrm{pH}$, biomass, and total carotenoids production and reducing sugar during $96 \mathrm{~h}$ in three culture media: Synthetic medium - YM; Extract pulp - EP and Husk extract - HE. Rhodotorula mucilaginosa CCMA 0156 (1A, 1B, and 1C); R. mu-

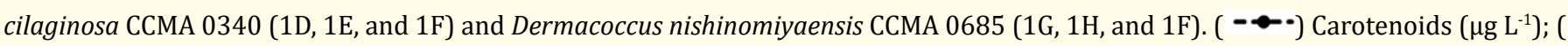
$\cdots \Delta \cdots)$ Reducing sugar $\left(\mathrm{mg} \mathrm{L}^{-1}\right) ;(\rightarrow-)$ Biomass $\left(\mathrm{g} \mathrm{L}^{-1}\right) ;(\multimap) \mathrm{pH}$.

reported that carotenoid formation was associated with the end of exponential growth phase. The maximum total carotenoid production $\left(3.426 \mu \mathrm{g} \mathrm{L}^{-1}\right)$ and biomass $\left(11.2 \mathrm{~g} \mathrm{~L}^{-1}\right)$ were observed at $90 \mathrm{~h}$ of fermentation during the stationary phase.

\section{Plackett-Burman design}

After analysis of the Plackett-Burman (PB) experimental design observed the seven variables tested. When the pulp or hush extract was used influenced differently each experiment. The analysis of the PB to pulp extract showed that at $90 \%$ significance level, yeast extract, peptone and pulp extract were significant $(p<0.10)$ in the production of specific carotenoids by Rhodotorula mucilaginosa CCMA 0156. In the experiment with husk extract, among the variables tested that at $99 \%$ significance level, glucose, peptone, and husk extract were statistically significant $(\mathrm{p}<0.01)$ in the production of specific carotenoids.

\section{Optimization of carotenoid production by DCCR design}

The results observed that there were significant relationships between the variables studied for specific carotenoids production when pulp and husk extract was used (Table 6 and 7).

\begin{tabular}{|c|c|c|c|c|}
\hline & $\begin{array}{c}\text { Regression } \\
\text { coefficient }\end{array}$ & $\begin{array}{l}\text { Pure } \\
\text { error }\end{array}$ & $t$ value & $p$ value \\
\hline Mean/Interc. ${ }^{*}$ & 325,52 & 28,58 & 11,38 & $0,0000^{*}$ \\
\hline$\left(\mathrm{X}_{1}\right)$ Pulp extract $(\mathrm{L})^{*}$ & 50,26 & 13,43 & 3,74 & $0,0072^{*}$ \\
\hline$\left(X_{1}\right)$ Pulp extract $(Q)^{*}$ & $-52,34$ & 14,79 & $-3,53$ & $0,0095^{*}$ \\
\hline$\left(\mathrm{X}_{2}\right)$ Peptone (L) & 13,45 & 13,43 & 1,00 & 0,3498 \\
\hline$\left(\mathrm{X}_{2}\right)$ Peptone $(\mathrm{Q})$ & $-2,83$ & 14,79 & $-0,19$ & 0,8535 \\
\hline$\left(\mathrm{X}_{3}\right)$ Yeast extract(L) & $-12,17$ & 13,43 & $-0,90$ & 0,3946 \\
\hline$\left(\mathrm{X}_{3}\right)$ Yeast extract $(\mathrm{Q})^{*}$ & $-35,56$ & 14,79 & $-2,4$ & $0,0472^{*}$ \\
\hline $\mathrm{X}_{1} \mathrm{~L}$ by $\mathrm{X}_{2} \mathrm{~L}$ & 1,50 & 17,54 & 0,08 & 0,9341 \\
\hline $\mathrm{X}_{1} \mathrm{~L}$ by $\mathrm{X}_{3} \mathrm{~L}$ & $-9,13$ & 17,54 & $-0,52$ & 0,6186 \\
\hline $\mathrm{X}_{2} \mathrm{~L}$ by $\mathrm{X}_{3} \mathrm{~L}$ & 14,73 & 17,54 & 0,84 & 0,4285 \\
\hline
\end{tabular}

Table 6: Model coefficients estimated by linear and quadratic regression multiples (significance of regression coefficients) of the evaluated factors (pulp extract, peptone, and yeast extract) to specific carotenoids production by Rhodotorula mucilaginosa CCMA 0156 responses in the central composition design in coffee pulp extract (PE).

*Significant $(p<0.05) . \mathrm{R}^{2}=0.82$. (L) linear effect and (Q) quadratic effect. 


\begin{tabular}{|c|c|c|c|c|}
\hline & $\begin{array}{c}\text { Regression } \\
\text { coefficient }\end{array}$ & $\begin{array}{l}\text { Pure } \\
\text { error }\end{array}$ & $t$ value & $p$ value \\
\hline Mean/Interc. ${ }^{*}$ & 213,72 & 19,52 & 10,94 & $0,0000^{*}$ \\
\hline$\left(\mathrm{X}_{1}\right)$ Glucose $(\mathrm{L})$ & 19,86 & 9,17 & 2,16 & 0,0671 \\
\hline$\left(\mathrm{X}_{1}\right)$ Glucose $(\mathrm{Q})$ & 12,94 & 10,10 & 1,28 & 0,2410 \\
\hline$\left(\mathrm{X}_{2}\right)$ Peptone $(\mathrm{L})^{*}$ & 22,11 & 9,17 & 2,41 & $0,0467^{*}$ \\
\hline$\left(\mathrm{X}_{2}\right)$ Peptone $(\mathrm{Q})$ & 0,36 & 10,10 & 0,03 & 0,9725 \\
\hline $\begin{array}{l}\left(\mathrm{X}_{3}\right) \text { Husk extract } \\
(\mathrm{L})^{*}\end{array}$ & 64,33 & 9,17 & 7,01 & $0,0002^{*}$ \\
\hline $\begin{array}{l}\left(\mathrm{X}_{3}\right) \text { Husk extract } \\
(\mathrm{Q})\end{array}$ & $-14,39$ & 10,10 & $-1,42$ & 0,1974 \\
\hline $\mathrm{X}_{1} \mathrm{~L}$ by $\mathrm{X}_{2} \mathrm{~L}$ & 3,43 & 11,98 & 0,28 & 0,7829 \\
\hline $\mathrm{X}_{1} \mathrm{~L}$ by $\mathrm{X}_{3} \mathrm{~L}^{*}$ & $-30,43$ & 11,98 & $-2,54$ & $0,0386^{*}$ \\
\hline $\mathrm{X}_{2} \mathrm{~L}$ by $\mathrm{X}_{3} \mathrm{~L}$ & 4,33 & 11,98 & 0,36 & 0,7280 \\
\hline
\end{tabular}

variables were built using the significant parameters (Equation 1 and 2).

$$
\begin{aligned}
& Y_{P E}=325.52+50.26 X_{1}^{2}-52.34 X_{1}^{2}-35.56 X_{3}--(1) \\
& Y_{H E}=213.72+22.11 X_{2}+64.33 X_{3}-30.43 X_{1} X_{3}--(2)
\end{aligned}
$$

Where, $\mathrm{Y}_{\mathrm{PE}}$ stands for specific carotenoids production in pulp extract: $X_{1}$ is pulp extract and $X_{3}$ represents yeast extract. $Y_{H E}$, carotenoids production in husk extract: $\mathrm{X}_{1}$ is glucose, $\mathrm{X}_{2}$ peptone, and $\mathrm{X}_{3}$ represents husk extract. The fits of the models were confirmed by the coefficient of determination $\left(\mathrm{R}^{2}\right)$ Being for pulp extract, $\mathrm{R}^{2}=$ 0.82 and husk extract, the coefficient of determination value is $R^{2}$ $=0.91$.

Three-dimensional response surface plots and was used to visualize the interaction effects of the variables related to specific carotenoid production and to determine their optimum ranges for maximum production. Figure 2 shows the response surface of specific carotenoids coffee extract pulp and coffee extract husk production. Plot 2A reveals higher specific carotenoids production for higher peptone (10.04 $\left.\mathrm{g} \mathrm{L}^{-1}\right)$ concentration and average amount (center point) of yeast extract $\left(3 \mathrm{~g} \mathrm{~L}^{-1}\right)$. Plot $2 \mathrm{~B}$ illustrates that higher pigment production occurred at higher peptone $\left(10.04 \mathrm{~g} \mathrm{~L}^{-1}\right)$ concentration associated with pulp extract $\left(6.68 \mathrm{~g} \mathrm{~L}^{-1}\right)$ concentration near center point. Plot 2C shows higher production when pulp extract (6.68 $\mathrm{g} \mathrm{L}^{-1}$ ) concentration near center point was associated with average amount (center point) of yeast extract $\left(3 \mathrm{~g} \mathrm{~L}^{-1}\right)$.

From that was determined the regression coefficients for the specific carotenoid response. The following models with codified

A

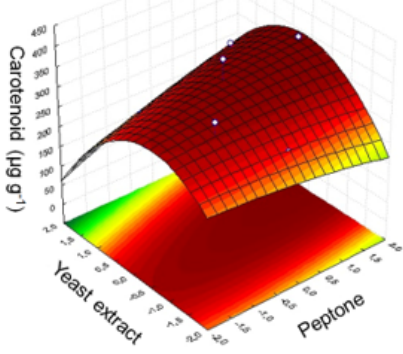

D

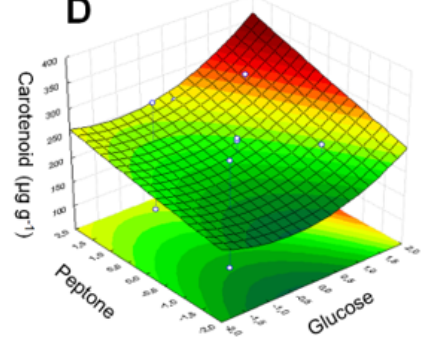

B

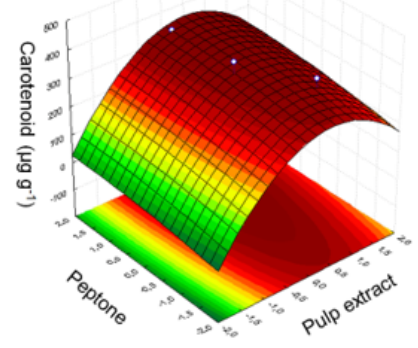

E

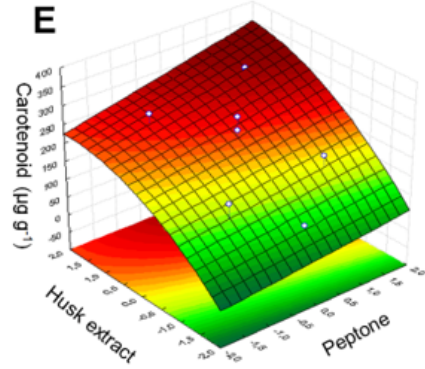

C

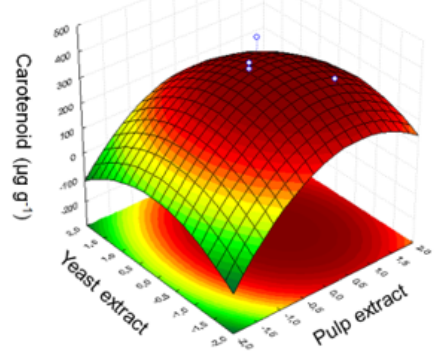

$\mathbf{F}$

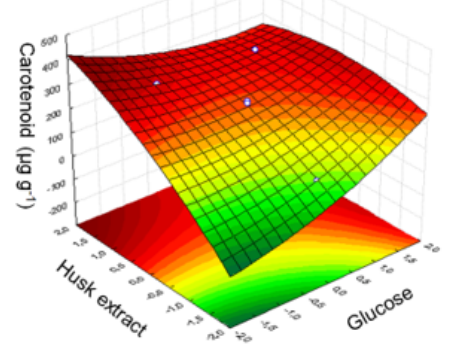

Figure 2: Surface plots of the responses in specific carotenoids production by Rhodotorula mucilaginosa CCMA 0156 in coffee pulp extract and coffee husk extract. (A) Specific carotenoids production as a function of yeast extract and peptone. (B) Specific carotenoids production as a function of concentration of coffee pulp extract and peptone. (C) Specific carotenoids production as a function of concentration of coffee pulp extract and yeast extract. (D) Specific carotenoids production as a function of peptone and glucose. (E) Specific carotenoids production as a function of concentration of coffee husk extract and peptone. (F) Specific carotenoids production as a function of concentration of coffee husk extract and glucose. 
The maximum content of specific carotenoids was obtained in the tests corresponding to the axial point (1.68) so the highest value of each variable $\left(6.36 \mathrm{~g} \mathrm{~L}^{-1}\right.$ glucose, $3.68 \mathrm{~g} \mathrm{~L}^{-1}$ peptone and $8.36 \mathrm{~g} \mathrm{~L}^{-1}$ husk extract). Husk extract and peptone concentration influenced positively the response. Plot $2 \mathrm{D}-2 \mathrm{~F}$ show that specific carotenoids production was affected by the independent variable peptone and glucose, husk extract and peptone, husk extract and glucose, respectively.

The production of carotenoids by $R$. mucilaginosa CCMA 0156 R. mucilaginosa CCMA 0340 and Dermacoccus nishinomiyaensis CCMA 0685 was tested by two naturals medium (pulp extract and husk extract) without addition of nutrients to assess the ability of microorganisms to ferment carbon sources of the substrate and synthesize carotenoids. Simultaneously, a complex synthetic medium (YM) was used as control. The results demonstrate that the extract of pulp and husk coffee can be used in the production of carotenoids and replace the synthetic means in industrial processes, thus reducing the operation costs. Moreover, many other factors involved in the processes can affect the yields and operation costs [13].

One of the most important factors to consider is the carbon source. Carbon source is the most studied parameter to influence carotenogenesis. Metabolism of yeasts acts depending on the kind of carbon source in the medium [36]. Sucrose and glucose are carbon sources most used in the production of carotenoids [20]. In our study, the synthetic YM medium was used as a control to compare the growth and accumulation of intracellular carotenoids among strains with natural means (coffee pulp extract and husk extract). R. mucilaginosa CCMA 0156 and R. mucilaginosa CCMA 0340 consumed the sugars faster than D. nishinomiyaensis CCMA 0685 in different medium tested, whereas in synthetic medium the glucose was consumed almost totally. Already in extracts of pulp and husk coffee, besides of glucose, others sugar such as sucrose, fructose, arabinose, galactose, maltose, and polysaccharides could be present [37], which may have slowed down the consumption of reducing sugars by the microorganisms.

Marova., et al. [25], used an agro-industrial waste as a substrate for production of carotenoids and biomass by yeasts Sporobolomyces roseus, Rhodotorula glutinis, Rhodotorula mucilaginosa. The best production of biomass ( $45 \mathrm{~g} \mathrm{~L}^{-1}$ ) and $\beta$-carotene $\left(56 \mathrm{mg} \mathrm{L}^{-1}\right)$ was obtained in a medium containing whey with cultivation of $R$ glutinis. Banzatto., et al. [38], studied the production of biomass and carotenoid by Rhodotorula rubra in molasses and cane syrup supplemented with two nitrogen sources. The intracellular carotenoid production was increased in all studied media without supplementation $\left(0.329 \mathrm{mg} \mathrm{g}^{-1}\right)$. According to the authors, biomass production and pigment differs according to the type of substrate used. As observed in our results, the production of biomass and carotenoids by R. mucilaginosa CCMA 0156, R. mucilaginosa CCMA 0340 and D. nishinomiyaensis CCMA 0685 was different in each fermentation medium (YM, PE and HE). YM being a synthetic medium, there were three different sources of nitrogen $\left(3 \mathrm{~g} \mathrm{~L}^{-1}\right.$ yeast extract, $3 \mathrm{~g} \mathrm{~L}^{-1}$ of malt extract and $5 \mathrm{~g} \mathrm{~L}^{-1}$ peptone) and $10 \mathrm{~g} \mathrm{~L}^{-1}$ of glucose as a source of carbon, already in natural medium (PE and HE), carbon source was carbohydrates and nitrogen source was proteins.

In addition to the different sources of carbon and nitrogen which are associated with the microbial production of carotenoids, the $\mathrm{pH}$ is one of the most important physical parameters for consideration. In this study, during the production of carotenoids by Rhodotorula mucilaginosa CCMA 0340, R. mucilaginosa CCMA 0156 and Dermacoccus nishinomiyaensis CCMA 0685 In coffee pulp extract and husk extract, remained constant until $48 \mathrm{~h}$ of fermentation. After this period, all crops increased the $\mathrm{pH}$ around 7 until the end of fermentation. The coffee pulp extract and husk extract are more acidic than the synthetic medium (pH 6), whose $\mathrm{pH}$ is close to 5 , this fact may explain why the $\mathrm{pH}$ remained stable in the media in the early hours of fermentation. The strong influence of $\mathrm{pH}$ in product and cell yield was evidenced being. The highest yields $\left(\mathrm{Y}_{\mathrm{P} / \mathrm{x}}\right.$ $=1.74 \mathrm{mg} \mathrm{g}^{-1}$ and $\mathrm{Y}_{\mathrm{P} / \mathrm{S}}=0.36 \mathrm{mg} \mathrm{g}^{-1}$ ) were found with $\mathrm{pH}$ control set at $6.0 \mathrm{up}$ to $80 \mathrm{~h}$ and then set to $4.0 \mathrm{up}$ to the end of bio-production [39].

\section{Validation of the experimental design}

Thus, the optimal conditions of the culture medium (PE) were as follows: pulp extract $6.68 \%$, peptone $10.04 \mathrm{~g} \mathrm{~L}^{-1}$, and yeast extract $3 \mathrm{~g} \mathrm{~L}^{-1}$. The model predicted that the production of carotenoids could reach a value of $347.54 \mu \mathrm{g} \mathrm{g}^{-1}$ (Eq. 1). The optimal conditions of the culture medium (HE) were as follows: glucose $6.36 \mathrm{~g} \mathrm{~L}^{-1}$, peptone $3.68 \mathrm{~g} \mathrm{~L}^{-1}$, and husk extract $8.36 \%$. The model predicted that the production of carotenoids could reach a value of $325.29 \mu \mathrm{g} \mathrm{g}^{-1}$ (Eq. 2). To confirm the model's adequacy in predicting the highest specific carotenoids yield, three additional experiments were performed using these optimized conditions. The mean production of specific carotenoids obtained from these validation experiments was $361.29 \pm 36.0 \mu \mathrm{g} \mathrm{g}^{-1}(\mathrm{PE})$ and $296.58 \pm 13.2 \mu \mathrm{g} \mathrm{g}^{-1}$ (HE), in agreement with the predicted values. The results verified the models and the optimal points.

Figure 3 shows the fermentation parameters monitored during the time carotenoids production (0, 48 and $120 \mathrm{~h}$ ) by Rhodotorula mucilaginosa CCMA 0156 in validation assays in pulp extract and coffee husk extract. The yeast had similar behavior in both medium once the production of carotenoids was accompanied by increased of biomass and consumption reducing sugars. However, the production of biomass in the fermentation was relatively higher in 
husk extract (HE) $\left(6.6 \mathrm{~g} \mathrm{~L}^{-1}\right)$ than pulp extract (PE) $\left(4.5 \mathrm{~g} \mathrm{~L}^{-1}\right) 120 \mathrm{~h}$ of cultivation, whereas the concentration and consumption was greater in husk extract. This may have occurred because the consumption of reducing sugar HE was higher than in PE coming to the reduction of $72.65 \%$ and $50 \%$, respectively, at the end of fer- mentation. Consequently, the production of total carotenoids was $3.2 \mathrm{x}$ higher in HE (114.02 $\left.\mathrm{g} \mathrm{L}^{-1}\right)$ than PE (44.39 $\mu \mathrm{g} \mathrm{L}^{-1}$ ) (Figure 3). The initial $\mathrm{pH}$ in both medium was about 4.5 , remained constant in the first $48 \mathrm{~h}$ and then had a slight increase of about 5.6 (PE) and 6.7 (HE).
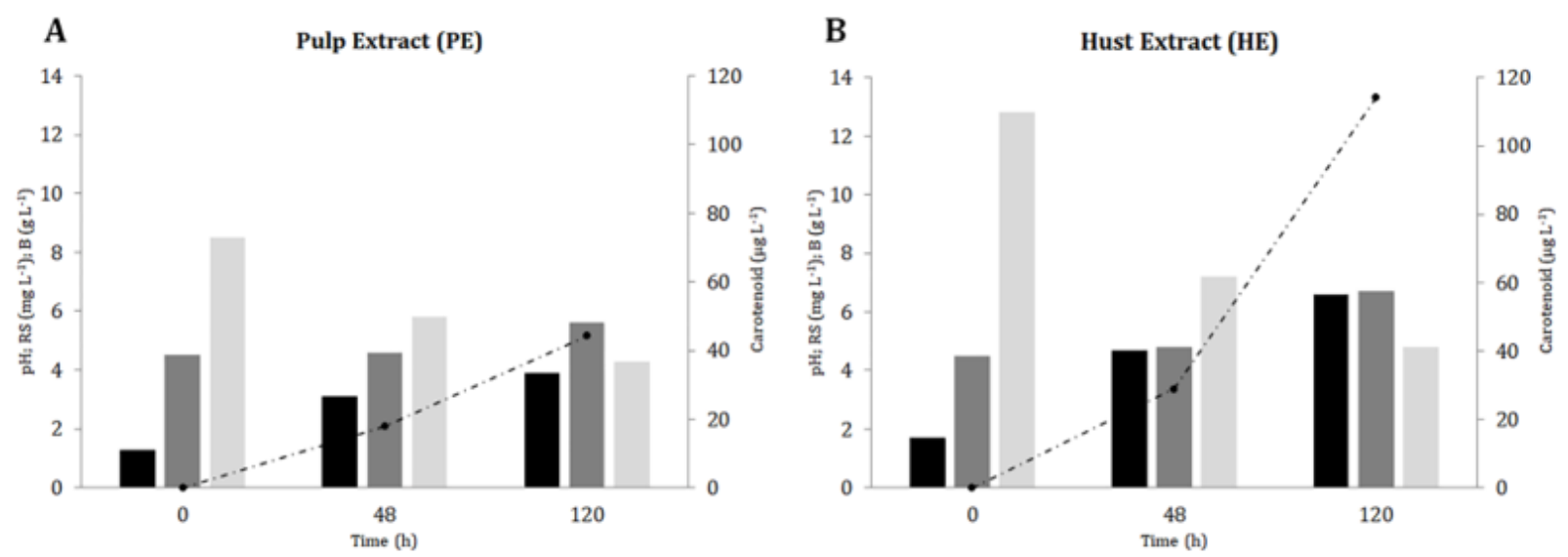

Figure 3: Fermentation profile of Rhodotorula mucilaginosa CCMA 0156 during the production of total carotenoids. (A) Coffee Pulp extract and (B) Coffee husk extract in the validation experiments on $120 \mathrm{~h}$ at $28{ }^{\circ} \mathrm{C}, 160 \mathrm{rpm}$ in the dark. ( $\left.-\bullet^{-}\right)$Carotenoids $\left(\mu \mathrm{g} \mathrm{L}^{-1}\right)$; (

R. mucilaginosa CCMA 0156 was the strain that showed the best results in the production of carotenoids using coffee pulp extract and husk extract compared with $R$. mucilaginosa CCMA 0340 and D. nishinomiyaensis CCMA 0685. The production of carotenoids by R. mucilaginosa using agro-industrial substrates (sucrose lactose whey and molasses) was also studied by Rodrigues., et al. [40]. The authors reported that in general, the increase in sugar concentration increased the growth of yeast and the total carotenoids production (89 $\mathrm{mg} \mathrm{L}^{-1}$ ) was obtained when $20 \mathrm{~g} \mathrm{~L}^{-1}$ sucrose molasses was used the carbon source. Similarly, Aksu and Eren [41], studied the carotenoid production by Rhodotorula glutinis concluding that an increase in sugar concentrations (initial glucose concentration $5 \mathrm{~g} \mathrm{~L}^{-1}$ ) in the growth medium increased the growth of yeast and carotenoid production (69 $\mathrm{mg} \mathrm{L}^{-1}$ ).

Carotenoids production by fermentation can become industrially feasible if the cost of production can be minimized by use of cheap industrial by-products as nutrient sources. Several researchers have investigated carotenoids production from various grains (oats, wheat, barley, corn, rice, rye), lipids and related substances, glycerol, cellobiose, sugar cane molasses, grape must, and cheese whey by different strains in shake flask fermentation $[25,42,43]$.

\section{Conclusion}

The coffee processing residues proved potential by-products for use as culture media to produce microbial carotenoids. Future work can be focused on the functional and structural characterization studies of these molecules can be utilized for possible industrial use.

\section{Acknowledgements}

The authors thank the Brazilian agencies Conselho Nacional de Desenvolvimento Científico e Tecnológico do Brasil (CNPQ), Fundação de Amparo à Pesquisa do Estado de Minas Gerais (FAPEMIG) and Coordenação de Aperfeiçoamento de Pessoal de Nível Superior (CAPES) for scholarship. Thanks to the Culture Collection of Microorganisms of Agricultural Microbiology (CCMA), Federal University of Lavras - UFLA for supplying the strains used in this study. 


\section{Conflict of Interest}

Authors declare that they have no conflict of interest.

\section{Bibliography}

1. El-Agamey A., et al. "Carotenoid radical chemistry and antioxidant/pro-oxidant properties". Archives of Biochemistry and Biophysics 430.1 (2004): 37-48.

2. Ursache FM., et al. "Valorization of carotenoids from sea buckthorn extract by microencapsulateion and formulation of value-added food products". Journal of Food Engineering 219 (2018): 16-24.

3. Chaari M., et al. "Encapsulation of carotenoids extracted from halophilic Archaea in oil-in-water (O/W) micro- and nanoemulsions". Colloids and Surfaces B: Biointerfaces 161 (2018): 219-227.

4. Montero-Lobato Z., et al. "Optimization of growth and carotenoid production by Haloferax mediterranei using response surface methodology". Marine Drugs 16.10 (2018): 372-384.

5. Rivera S M and Canela-Garayoa R. "Analytical tools for the analysis of carotenoids in diverse materials". Journal of Chromatography $A 1224$ (2012): 1-10.

6. Marova I., et al. "Production of carotenoid/ergosterol supplemeted biomass by red yeast Rhodotorul aglutinis grown under external stress". Food Technology and Biotechnology 48 (2010): 56-61.

7. Cardoso L A C., et al. "Biotechnological production of carotenoids and their applications in food and pharmaceutical products". Carotenoids, Intech Open (2017): 125-142.

8. Calegari-Santos R., et al. "Carotenoid production by halophilic archaea under different culture conditions". Current Microbiology 72 (2016): 641-651.

9. Urnau L., et al. "Extraction of carotenoids from Xanthophyllomyces dendrorhous using ultrasound-assisted and chemical cell disruption methods". The Canadian Journal of Chemical Engineering 96.6 (2018): 1377-1381.

10. Nanou K and Roukas T. "Waste cooking oil: A new substrate for carotene production by Blakeslea trispora in submerged fermentation". Bioresource Technology 203 (2016): 198-203.
11. Heer K and Sharma S. "Microbial pigments as a natural color: A review". Intenational Journal of Pharmaceutical Sciences and Research 8.5 (2017): 1913-1922.

12. Michelon M., et al. "Extraction of carotenoids from Phaffia rhodozyma: A comparison between different techniques of cell disruption". Food Science and Biotechnology 21 (2012): 1-8.

13. Mata-Gómez L C., et al. "Biotechnological production of carotenoids by yeasts: an overview". Microbial Cell Factories 13 (2014): 1-12.

14. Yan F., et al. "Ultrasonic-assisted solvent extraction of carotenoids from rapessed meal: optimization using response surface methodology". Journal of Food Quality 38.6 (2015): 377386.

15. Chuyen H V., et al. "Optimisation of extraction conditions for recovering carotenoids and oxidant capacity from Gac peel using response surface methodology". International Journal of Food Science and Technology 52.4 (2017): 972-980.

16. Monks L., et al. "Assessment of carotenoids recovery through cell rupture of Sporidiobolus salmonicolor CBS 2636 using compressed fluids". Food and Bioprocess Technology 5 (2012): 2353-2359.

17. AOAC: Association of Official Analytical Chemists. Official methods of analysis of the association of official analytical chemists: 16 ed., Washington (1995).

18. Machado C M M., et al. "Gibberellic acid production by solidstate fermentation in coffee husk". Applied Biochemistry and Biotechnology 15 (2002): 102-106.

19. Dubois M., et al. "Colorimetric method for determination of sugar and related substances". Analytical Chemistry 28.3 (1956): 350-356.

20. Valduga E., et al. "Assessment of cell disruption and carotenoids extraction from Sporidiobolus salmonicolor (CBS 2636)". Food and Bioprocess Technology 2 (2009): 234-238.

21. Silva C F., et al. "Microbiota presente em frutos e grãos de café (Coffea arabica L.) despolpado e natural - Uma revisão". Boletim da Sociedade Brasileira de Ciência e Tecnologia de Alimentos, Campinas 37 (2004): 22-28. 
22. Davies B H. “Carotenoid”. In: Goodwin T W. Chemistry and Biochemistry of Plant Pigments. Academic Press, (1976): 38-165.

23. Miller G L. "Use of dinitrosalicylic acid reagent for determination of reducing sugar". Analytical Chemistry 31.3 (1959): 426428.

24. Plackett R L and Burman J P., et al. "The design of optimum multifactorial experiments". Biometrika 33 (1946): 305-332.

25. Marova I., et al. "Use of several waste substrates for carotenoidrich yeast biomass production". Journal of Environmental Management 95 (2012): S338-S342.

26. Braunwald T., et al. "Effect of different $\mathrm{C} / \mathrm{N}$ ratios on carotenoid and lipid production by Rhodotorula glutinis". Applied Microbiology and Biotechnology 97 (2013): 6581-6588.

27. Murthy P S and Naidu M M. "Sustainable management of coffee industry by-products and value addition - A review". Resources, Conservation and Recycling 66 (2012): 45-58.

28. Janissen B and Huynh T. "Chemical composition and valueadding applications of coffee industry by-products: A review". Resources, Conservation and Recycling 128 (2018): 110-117.

29. Esquivel P and Jiménez V M. "Functional properties of coffee and coffee by-products". Food Research International 46 (2012): 488-495.

30. Bonilla-Hermosa V A., et al. "Utilization of coffee by-products obtained from semi-washed process for production of valueadded compounds". Bioresource Technology 166 (2014): 142150.

31. Sadh P K., et al. "Agro-industrial wastes and their utilization using solid state fermentation: a review". Bioresources and Bioprocessing 5.1 (2018): 1-15.

32. Saini R K and Keum Y S. "Carotenoid extraction methods: A review of recent developments". Food Chemistry 240 (2018): 90-103.

33. Tavanandi HA., et al. "Synergistic method for extraction of high purity Allophycocyanin from dry biomass of Arthrospira platensis and utilization of spent biomass for recovery of carotenoids". Separation and Purification Technology 225 (2019): 97-111.
34. Naghavi FS., et al. "Evalution of the relationship between the incubation time and carotenoid production in Rhodotorula slooffiae and R. mucilaginosa isolated from leather tanning wastewater". Iranian Journal of Basic Medical Sciences 16.10 (2013): 1114-1118.

35. Valduga E., et al. "Evaluation of aeration and substrate concentration on the production of carotenoids by Sporidiobolus salmonicolor (CBS 2636) in bioreactor". European Food Research and Technology 232 (2011): 453-460.

36. Marcoleta A., et al. "Glucose and ethanol-dependent transcriptional regulation of the astaxanthin: biosynthesis pathway in Xanthophyllomyces dendrorhous". BCM Microbiology 11 (2011): 190.

37. ABIC: Associação Brasileira da Indústria de Café (2015).

38. Banzatto D., et al. "Carotenoid production by Rhodotorula rubra cultivated in sugarcane juice, molasses and syrup". Ciência e Tecnologia de Alimentos 33 (2013): 14-18.

39. Hu Z C., et al. "pH control strategy in astaxanthin fermentation bioprocess by Xanthophyllomyces dendrorhous". Enzyme and Microbial Technology 39 (2006): 586-590.

40. Rodrigues T V D., et al. "Carotenoid production by Rhodotorula mucilaginosa in batch and fed-batch fermentation using agroindustrial byproducts". Food Technology and Biotechnology 57. 3 (2019): 388-398.

41. Aksu Z and Eren A T. "Production of carotenoids by the isolated yeast of Rhodotorula glutinis". Biochemical Engineering Journal 35 (2007): 107-113.

42. Schneider T., et al. "Lipid and carotenoid production by oleaginous red yeast Rhodotorula glutinis cultivated on brewery effluents". Energy 30 (2013): 1-10.

43. Elfeky N., et al. "Lipid and Carotenoid Production by Rhodotorula glutinis with a Combined Cultivation Mode of Nitrogen, Sulfur, and Aluminium Stress". Applied Sciences 9.12 (2019): 2444.

\section{Volume 4 Issue 9 September 2021 (C) All rights are reserved by Cristina Ferreira Silva., et al.}

